\title{
O desempenho científico da química portuguesa
}

No nosso país as instituições de ensino superior têm vivido muito sob o slogan "rankings, nem pensar!". Quaisquer que sejam as razões e sensibilidades para uma tal atitude, não é mais possível ignorar esta pressão para a competitividade quando o Thomson Institute for Scientific Information, que também organiza o Science Citation Index, compila tais dados a nível mundial e apresenta-os na plataforma Essential Science Indicators (ESI). São disponibilizados rankings de investigadores, de instituições, de países e de revistas científicas, durante cerca de 10 anos (1995-Julho 2006). Como fonte de informação da qualidade da investigação científica, esta base de dados, com as suas deficiências e matizes, é indiscutivelmente um referencial fiável e imparcial. Está subdividida em 22 áreas científicas, desde as denominadas "ciências duras" até às mais "moles".

Exemplificando com a Química, das pouco mais de 76000 instituições a nível mundial, a base do ESI regista as 762 instituições académicas com melhores desempenho em termos do número de citações: o topo $1 \%$. Em termos de países regista o topo 50\%, e para a mesma a área, o ranking regista 88 países o que significa que o universo mundial, considerado em países ou territórios, é de 176 países.

Para nos debruçarmos sob a problemática dos rankings de áreas científicas em Portugal convém examinar um pequeno número de indicadores de desempenho que permitam examinar a questão sob

* Professor Catedrático da Universidade de Coimbra (sformosinho@qui.uc.pt) ângulos distintos. Contudo, o número de indicadores em exame não deve ser tão elevado que nos faça perder a visão do todo.

A Tabela agrupa os doze domínios com melhor desempenho científico no nosso país e dispõem-nos por ordem decrescente do número total de citações. A Tabela mostra também se a respectiva área está melhor colocada no ranking mundial em termos do número de citações (o default do ESI) ou de artigos: 0 indicador $-\Delta\left(P_{n^{\circ}{ }^{\circ i t}}-P_{n^{\circ} a r t}\right)$. Considera-se positivo o estar melhor colocado em termos de citações do que em artigos. Exemplificando para a Química, um $-\Delta\left(P_{n^{\circ}{ }^{\circ} i t}-P_{n^{\circ} a r t}\right)=5$ significa que Portugal ocupa a 29. ${ }^{a}$ posição em termos do $n$. de citações e o $34 .^{\circ}$ lugar no $n .^{\circ}$ total de artigos. Não obstante, em artigos publicados, que não em citações, a Química é a área de topo em Portugal, o que se compreende pelos intrinsecamente maiores Factores de Impacto das ciências da vida em relação às ciências físicas e químicas (cerca de 3 vezes).

Para cada instituição, já o referimos, ESI só destaca as áreas que estão no top $1 \%$ mundial em termos de citações. Tais áreas permitem definir um índice-Rk (número de áreas científicas no ranking mundial) para cada universidade e igualmente verificar em quantas universidades portuguesas uma dada área científica se encontra neste exigente ranking, $\mathrm{N}^{\circ}-R k$. A química figura neste tipo de ranking em cinco universidades: IST/UTL, Coimbra, Nova de Lisboa, Aveiro e Porto, ocupando a primeira posição em Coimbra, Nova de Lisboa e Aveiro e a segunda nas duas restantes. As áreas no ranking mundial são fixadas em termos do número de citações e são revistas periodicamente. Por exemplo, a Medicina Clínica na Universidade de Coimbra não figurava neste ranking em Janeiro de 2006, passou a figurar em Maio de 2006 e deixou de figurar novamente em Julho, pelo que contabilizamo-la em 0,5.

As comparações mundiais têm indiscutivelmente um factor de dimensão. A confrontação com alguns Departamentos de química europeus mostra que, em parte, a nossa posição resulta de um menor número de professores e da nossa base social de pouca competitividade que tende a manter os seus professores independentemente do desempenho científico. Contudo, o haver instituições portuguesas a figurar neste exigente índice- $R k$ é significativo. Nelas assentam, no presente, motores de desenvolvimento científico, é certo que em pequeno número, mas será com eles que podemos contar para ter uma Universidade com melhor espírito crítico e um desempenho mais competitivo.

Indiscutivelmente os vários indicadores que referimos apontam para a Química como a área científica com melhor desempenho no país. A Física, que em Portugal teve uma tradição de desenvolvimento idêntica ao da Química, só figura no ranking mundial no IST/UTL. A Ciência dos Materiais constitui uma agradável surpresa pela posição em que coloca Portugal e pelo número de instituições (IST, Aveiro, Porto e Minho) que se encontra no ranking mundial. A posição das Engenharias é boa, mas tal decorre, em parte, por ser um índice agregado para todas as classes de engenharias. 